\title{
ESTUDOS DE CASO SOBRE DESENVOLVIMENTO E UTILIZAÇÃO DE PROJETOS PARA PRODUÇÃO DE VEDAÇÕES VERTICAIS
}

\author{
Janayna AQUINO \\ Engenheira Civil, Mestre em Engenharia Civil, \\ Coordenadora de Projetos da Construtora Tarjab \\ janayna@tarjab.com.br
}

\section{Silvio MELHADO}

Engenheiro Civil, Livre-Docente em Tecnologia de Processos Construtivos, Professor Associado da Escola Politécnica da Universidade de São Paulo silvio.melhado@poli.usp.br

\section{RESUMO}

Este artigo resume uma pesquisa de mestrado realizada sobre as práticas adotadas e dificuldades encontradas no desenvolvimento e utilização de projetos para produção de vedações verticais nas construtoras, sob o ponto de vista da gestão (Aquino, 2004).

Os estudos de caso apresentados abrangem quatro empresas incorporadoras e construtoras, que atuam em São Paulo, e as empresas de projeto para produção de vedações verticais que estão vinculadas a estas. Inicialmente foi caracterizado do perfil das empresas construtoras, analisando-se como elas desenvolvem ou contratam o projeto para produção de vedações e as modalidades adotadas para sua execução.

Após a caracterização das empresas construtoras para compreender o fluxo de projeto e os seus agentes, prosseguiu-se com o estudo específico nas empresas de projeto para produção e nos canteiros de obras das empresas construtoras estudadas.

Conclui-se com a análise de vários aspectos importantes quanto à atuação das empresas construtoras, das empresas de projeto e quanto à interface dos projetos para produção de vedações verticais com a execução das obras.

Palavras-chave: construção de edifícios, projeto para produção, vedações verticais

\section{ABSTRACT}

This paper summarizes a research carried out, from the management viewpoint, on the practices commonly adopted and the main difficulties found in the development and use of the design for production of partitions and facades.

The case studies comprised four real estate and construction firms that build mainly in the city of Sao Paulo, and the design firms responsible for designs for production of partitions and facades that are linked to these enterprises. Firstly, the profile of these real estate and construction firms was outlined, including as they develop or hire a designer to develop the design for production of partitions and facades as well as the modalities adopted for their execution.

After outlining the real estate and construction firms to understand their design flows and the actors roles, the research followed throughout a specific analysis of design firms responsible for the design for production and also in the building sites of the studied construction firms.

The paper concludes with the analysis of several important remarks on the performance of these real estate and construction firms, on the specialised design firms and on the interface between the design for production of partitions and facades and their respective site works.

Keywords: building construction, design for production, partitions and facades 


\section{INTRODUÇÃO}

A pesquisa realizada priorizou a análise do processo de projeto interno às empresas construtoras e da inserção do projeto para produção de vedações verticais nesse processo, da relação entre os diversos agentes que contribuem para o seu desenvolvimento e os aspectos do canteiro de obras que interferem na sua utilização.

As empresas incorporadoras e construtoras estudadas foram selecionadas de modo a refletir a realidade do mercado de desenvolvimento dos projetos para produção de vedações verticais na cidade de São Paulo, que pode ser estendida para outros tipos de projetos para produção. Constata-se que o projeto para produção de vedações verticais é desenvolvido em outras capitais brasileiras e a sua importância tem sido propagada, mas este desenvolvimento ainda é "tímido" se comparado ao encontrado na cidade de São Paulo, que apresenta uma diversidade maior de projetistas desse tipo de projeto, tecnologia e materiais adequados mais acessíveis e mão-de-obra mais qualificada, fatores esses que são extremamente importantes para o desenvolvimento e utilização do projeto para produção de vedações verticais.

Discute-se o fluxo de projeto praticado por essas construtoras e o envolvimento dos agentes no processo de projeto, que se complementa com estudos específicos sobre as empresas de projeto para produção de vedações verticais e sobre a utilização desses projetos os canteiros de obras das empresas construtoras estudadas.

\section{MÉTODO DE PESQUISA}

\subsection{Identificação das possíveis relações entre empresas construtoras, projetistas de vedações verticais e equipes de execução}

O método de pesquisa adotado abrange o estudo dos diversos agentes que participam do processo de desenvolvimento e da utilização dos projetos para produção de vedações verticais na construção de edifícios. O conhecimento desses agentes e da relação entre eles é fundamental para a definição das reais atribuições de cada um no processo. Antes da realização dos estudos de caso, foram identificadas as variações encontradas no modo como o projeto para produção de vedações verticais é desenvolvido e utilizado na cidade de São Paulo, apresentadas no Quadro 1.

O Quadro 1 identifica as possibilidades de contratação, desenvolvimento e execução do projeto para produção de vedações verticais que são encontradas no mercado de construção de edifícios na cidade de São Paulo atualmente. As combinações dos itens apresentados nesse quadro geram as seguintes quinze possibilidades quanto às relações de trabalho:

1. A empresa construtora contrata o projeto para produção de vedações verticais de um único projetista, sendo esse projetista especializado, e contrata a mão-de-obra de um subempreiteiro (de acordo com o Quadro 1, combinação 1-1-1); 
2. A empresa construtora contrata o projeto para produção de vedações verticais de um único projetista, sendo esse projetista especializado, e utiliza mão-de-obra própria (de acordo com o Quadro 1, combinação 1-1-2);

3. A empresa construtora contrata o projeto para produção de vedações verticais de um único projetista, sendo esse projetista especializado e contrata a mão-de-obra desse projetista (de acordo com o Quadro 1, combinação 1-1-3);

4. A empresa construtora contrata o projeto para produção de vedações verticais de um único projetista, sendo esse projetista especializado e contrata a mão-de-obra de um outro projetista especializado, que não o autor do projeto (de acordo com o Quadro 1, combinação 1-1-4);

5. A empresa construtora contrata o projeto para produção de vedações verticais de um único projetista que é o próprio arquiteto autor do projeto arquitetônico de um empreendimento, e contrata a mão-de-obra de um subempreiteiro (de acordo com o Quadro 1, combinação 1-3-1);

\section{Inserção do PPVV na construção de edifícios -mercado de SP}

\section{Como o PPVV é contratado pelas} empresas construtoras?

1) Contratam o PPVV de um único projetista para vários empreendimentos

2) Contratam o PPVV de vários projetistas para diferentes empreendimentos

3) Não contratam, mas desenvolvem o PPVV internamente

4) Não contratam o PPVV porque não o utilizam

\section{Quem faz o PPVV?}

1) Projetista especializado

2) Equipe de projetistas do departamento de projetos da empresa construtora

3) Projetista é o próprio arquiteto autor do projeto arquitetônico

\section{Quem executa o PPVV em obra?}

1) Mão-de-obra subempreitada

2) Mão-de-obra própria da empresa construtora

3) Mão-de-obra subempreitada do mesmo projetista autor do PPVV

4) Mão-de-obra subempreitada de um outro projetista especializado

Quadro 1: Utilização do projeto para produção de vedações verticais (PPVV) na cidade de São Paulo - realidade de mercado

6. A empresa construtora contrata o projeto para produção de vedações verticais de um único projetista que é o próprio arquiteto autor do projeto arquitetônico de um empreendimento, e tem mão-de-obra própria (de acordo com o Quadro 1, combinação $1-3-2)$;

7. A empresa construtora contrata o projeto para produção de vedações verticais de um único projetista que é o próprio arquiteto autor do projeto arquitetônico de um empreendimento, e contrata a mão-de-obra de um projetista especializado (de acordo com o Quadro 1, combinação 1-3-4); 
8. A empresa construtora contrata o projeto para produção de vedações verticais de vários projetistas especializados para diferentes empreendimentos e utiliza mão-deobra de um subempreiteiro (de acordo com o Quadro 1, combinação 2-1-1);

9. A empresa construtora contrata o projeto para produção de vedações verticais de vários projetistas especializados para diferentes empreendimentos e utiliza mão-deobra própria (de acordo com o Quadro 1, combinação 2-1-2);

10. A empresa construtora contrata o projeto para produção de vedações verticais de vários projetistas especializados para diferentes empreendimentos e utiliza mão-deobra contratada do projetista autor do PVV (de acordo com o Quadro 1, combinação 21-3);

11. A empresa construtora contrata o projeto para produção de vedações verticais de vários projetistas especializados para diferentes empreendimentos e utiliza mão-deobra contratada de um projetista especializado que não é o autor do projeto para produção de vedações verticais (de acordo com o Quadro 1, combinação 2-1-4);

12. A empresa construtora desenvolve o projeto para produção de vedações verticais, por meio de equipe interna de projetistas, e utiliza mão-de-obra subempreitada (de acordo com o Quadro 1, combinação 3-2-1);

13. A empresa construtora desenvolve o projeto para produção de vedações verticais, por meio de equipe interna de projetistas, e utiliza mão-de-obra própria (de acordo com o Quadro 1, combinação 3-2-2);

14. A empresa construtora desenvolve o projeto para produção de vedações verticais, por meio de equipe interna de projetistas, e utiliza mão-de-obra subempreitada de um projetista especializado (de acordo com o Quadro 1, combinação 3-2-4);

15. A empresa construtora não utiliza projeto para produção de vedações verticais. Este caso não será estudado por não fazer parte do objeto de análise deste artigo.

O objetivo da identificação dessas relações foi direcionar o estudo proposto, além de identificar se os aspectos que diferenciam essas relações podem ou não contribuir para um melhor desenvolvimento do projeto para produção de vedações verticais e da sua utilização em obra. Não se pretendeu esgotar o tema, identificar a melhor relação ou apresentar uma relação ideal, pois existem questões organizacionais envolvidas nas práticas das empresas construtoras, que variam de empresa para empresa, e que contribuem para uma melhor utilização desse tipo de projeto. $\mathrm{O}$ foco foi colocado nas práticas organizacionais que as empresas utilizam e que podem contribuir para um melhor desenvolvimento e utilização do projeto para produção de vedações verticais.

Dentre as relações verificadas, as que mais comumente são empregadas na construção de edifícios em São Paulo são as relações dos tipos 1, 2 e 8, abrangendo a maior parte das empresas construtoras. As outras relações ocorrem em um número menor de empresas, destacando-se a relação 3, que vem crescendo, a qual apresenta a possibilidade de contratação do projeto juntamente com a mão-deobra. Destaca-se também a relação 12 como uma tentativa de algumas empresas do mercado para melhorar o desenvolvimento dos projetos para produção de vedações verticais. Neste artigo, serão analisadas as relações identificadas pelos números 1, 2, 8 e 12.

Identificadas as relações de trabalho existentes para o desenvolvimento e utilização do projeto para produção de vedações verticais, foram caracterizados os agentes 
envolvidos nesse processo que contribuem de forma significativa para o seu resultado.

São muitos os agentes envolvidos no processo de produção de edifícios, dentre os quais podem ser citados: as empresas construtoras, representadas pelos seus vários departamentos; as equipes de execução em obra; os projetistas de diversas especialidades; os fornecedores de materiais, mão-de-obra e equipamentos; os consultores técnicos; as entidades representativas do setor; os agentes de vendas imobiliárias; os investidores; entre outros.

Considera-se potencialmente significativa a importância de todos esses agentes para o processo de produção, mas destacam-se alguns deles por terem uma relação direta com o desenvolvimento e a utilização do projeto para produção de vedações verticais, como demonstrado no Quadro 2.

\section{Selecionar fornecedores e estabelecer parcerias que possibilitem um desenvolvimento tecnológico à EC. Realizar compra técnica com base no projeto, planejamento e} orçamento previstos

Fornecer materiais, equipamentos, mão-de-obra com preço e qualidade compatíveis com o mercado e com o projeto, sendo assegurada - -.-.-.---idade do fornecimento

\begin{abstract}
Fornecer subsídio à produção através da elaboração de procedimentos, planejamento, orçamento da execução, suporte tecnológico, definição das tecnologias construtivas utilizadas
\end{abstract}

Retroalimentação a EC quanto à viabilidade das tecnologias utilizadas, produtividade, qualidade e desempenho

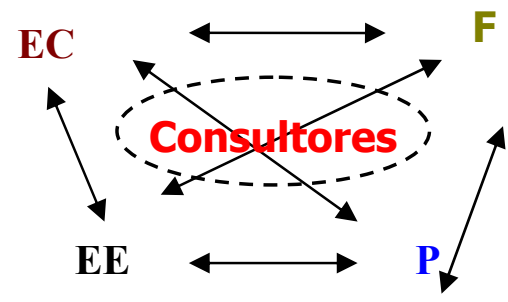

Assessorar a obra/ acompanhar a execução do projeto

Retroalimentar o projetista quanto às definições do
Dar suporte ao projetista na elaboração do projeto quanto às características e propriedades dos materiais, equipamentos e mão-de-obra a serem utilizados. Fornecer análise de desempenho dos materiais

Conhecer as características dos materiais e EC - P: Fornecer subsídio para elaboração dos projetos e suas interfaces. Acompanhar o
desenvolvimento do processo de projeto

Definir os elementos do edifício e da sua execução com base em critérios técnicos/ dar suporte no desenvolvimento tecnológico. Fornecer elementos que possibilitem a compra técnica

EE - F: Retroalimentar os fornecedores

Fornecer materiais e equipamentos no prazo e com a qualidade requerida. Fornecer mão-de-obra que execute com a produtividade e qualidade requeridas

EC - Atribuições da empresa construtora representada pelos seus diversos departamentos (projeto, planejamento, orçamento, suprimentos)

P - Atribuições dos projetistas

EE - Atribuições das Equipes de execução

F - Atribuições dos fornecedores

Consultores - subsídio aos diversos agentes na tomada de decisões

Quadro 2: As relações entre os principais agentes do processo de desenvolvimento do projeto para produção de vedações verticais 
Para cada um desses agentes definiu-se o objetivo da análise e o método correspondente para a coleta de dados com base na relação entre eles; a apresentação detalhada dos objetivos e métodos adotados para cada agente pode ser encontrada em AQUINO (2004), tendo sido suprimida deste artigo para maior concisão.

O Quadro 2 demonstra as relações ideais entre esses agentes, e não propriamente as que se estabelecem na prática. A identificação desses agentes e das relações necessárias entre eles conduz a uma comparação entre o ideal e o que ocorre no mercado. $\mathrm{O}$ modo como essas relações realmente acontecem é importante para se entender o processo de desenvolvimento do projeto para produção de vedações verticais e sua utilização no canteiro de obras.

\subsection{Aspectos analisados nos casos estudados}

A análise dos casos foi realizada sob dez aspectos, identificados abaixo, de (a) a (j), relativos à interface do projeto para produção de vedações verticais com o processo de projeto da empresa construtora, com a obra e com a tecnologia utilizada:

\section{$\underline{\text { Interface com o processo de projeto }}$}

(a) Participação do projetista de vedações no processo de projeto e a sua relação com as demais disciplinas do projeto durante o seu desenvolvimento;

(b) Fase do processo de projeto em que ocorre a contratação do projeto para produção de vedações verticais;

\section{$\underline{\text { Interface com a tecnologia }}$}

(c) Tecnologia adotada como solução do projeto para produção de vedações verticais;

(d) Qualidade da solução técnica adotada;

Interface com a obra

(e) Apresentação do projeto para produção de vedações verticais em obra pelo projetista;

(f) Suporte do projetista à obra;

(g) Contratação de subempreiteiros;

(h) Treinamento da mão-de-obra;

(i) Gestão da logística e da informação no canteiro de obras;

(j) Retroalimentação do projeto para produção de vedações verticais para o departamento de projetos da empresa construtora e para o projetista durante e após a sua utilização em obra.

\section{ESTUDOS DE CASO}

\subsection{O processo de projeto na empresa construtora A}

A empresa A atua no setor de incorporação e construção de edifícios desde 1977, lança de seis a oito empreendimentos por ano e apresentava aproximadamente 300 funcionários, na ocasião do estudo. Essa empresa apresenta um departamento de projeto, subordinado à Diretoria Técnica, composto pelo Gerente de Projetos, dois Coordenadores de Projeto, um projetista e uma estagiária. 
A empresa não desenvolve projetos internamente; contrata todos os projetos necessários. Além dos projetos ditos convencionais, como arquitetura, estrutura, fundação, instalações elétricas e hidráulicas, paisagismo, interiores, ar condicionado, esquadrias, dentre outros, também contrata os projetos para produção de fôrmas de madeira, de vedações e de fachada. O primeiro projeto para produção utilizado pela empresa foi o projeto para produção de vedações verticais, há dez anos. O fluxo de projeto existente na empresa pode ser visualizado na Figura 1.

Nesse fluxo, as decisões relativas ao lançamento de um empreendimento são tomadas pela diretoria de novos negócios, ligada à incorporação, juntamente com o presidente da empresa, os quais "delineiam" o produto. O produto é definido com base em pesquisa de mercado quanto à tipologia e uma série de outros fatores diretamente relacionados ao próprio produto como viabilidade econômica, custos, etc. Tendo-se traçado o perfil do novo empreendimento, o arquiteto é quem dá as primeiras diretrizes quanto à definição do pavimento tipo do edifício, incluindo estudos preliminares.

Dessa forma, o projeto arquitetônico é encaminhado ao departamento de projetos da empresa e é repassado pelo Gerente de Projetos aos projetistas de algumas especialidades, como estruturas, exaustão, hidráulica, para que haja uma préanálise, antes de o projeto ser enviado à prefeitura. Esse procedimento contribui para que o projeto não seja tão modificado após a sua aprovação pelos órgãos competentes, tendo já sido analisado por outros projetistas.

Após a aprovação do projeto, que dá origem ao projeto legal, os demais projetistas são contratados formalmente e iniciam o desenvolvimento dos diversos anteprojetos. Destaca-se que o projeto para produção de vedações verticais só é contratado na etapa de projeto executivo, quando os demais projetos já estão formalizados.

São feitas geralmente três reuniões para a coordenação do projeto, normalmente no início da contratação dos projetistas, após o término dos anteprojetos e após os préexecutivos. O processo prossegue, passando pelos projetos pré-executivo e executivo, até o detalhamento final. Os padrões para apresentação do projeto em obra são definidos pela própria empresa projetista, variando em alguns casos. 


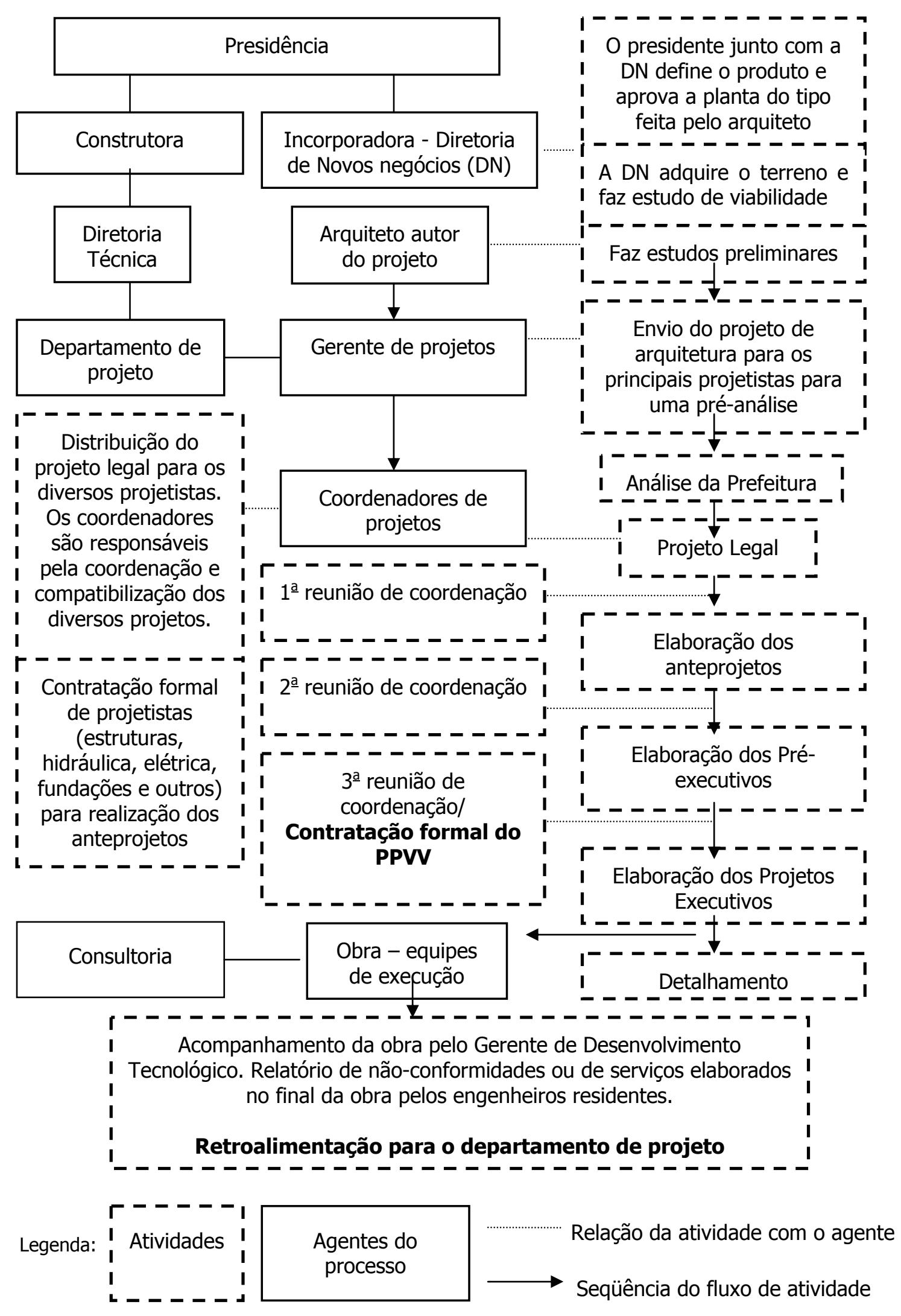

Figura 1: 0 Processo de Projeto na Empresa A 


\subsection{O processo de projeto na empresa construtora B}

A empresa B atua no mercado de incorporação e construção desde 1983, tendo oito obras em andamento com cerca de 240 funcionários próprios e 600 funcionários subcontratados, na ocasião do estudo realizado.

Essa empresa apresenta um departamento de projetos composto pelo Gerente de Projetos e Planejamento e dois estagiários. Todos os projetos da empresa são realizados externamente por empresas especializadas. Os primeiros projetos para produção utilizados pela empresa foram o projeto para produção de vedações verticais há onze anos e o projeto de fôrmas há sete anos. O papel do Coordenador de Projetos é exercido pelo próprio Gerente de Projetos que realiza a coordenação, a compatibilização e a revisão de todos os projetos contratados pela empresa.

O coordenador de projetos ressaltou o aumento da cooperação entre os diversos projetistas, principalmente os de arquitetura e de estruturas, que teve início com a contratação do projeto para produção de vedações verticais em 1993, que "força" a compatibilização entre os projetos, já que ele solicita muitas informações dos outros projetistas.

A figura 2 retrata o esquema de desenvolvimento de projetos da empresa B.

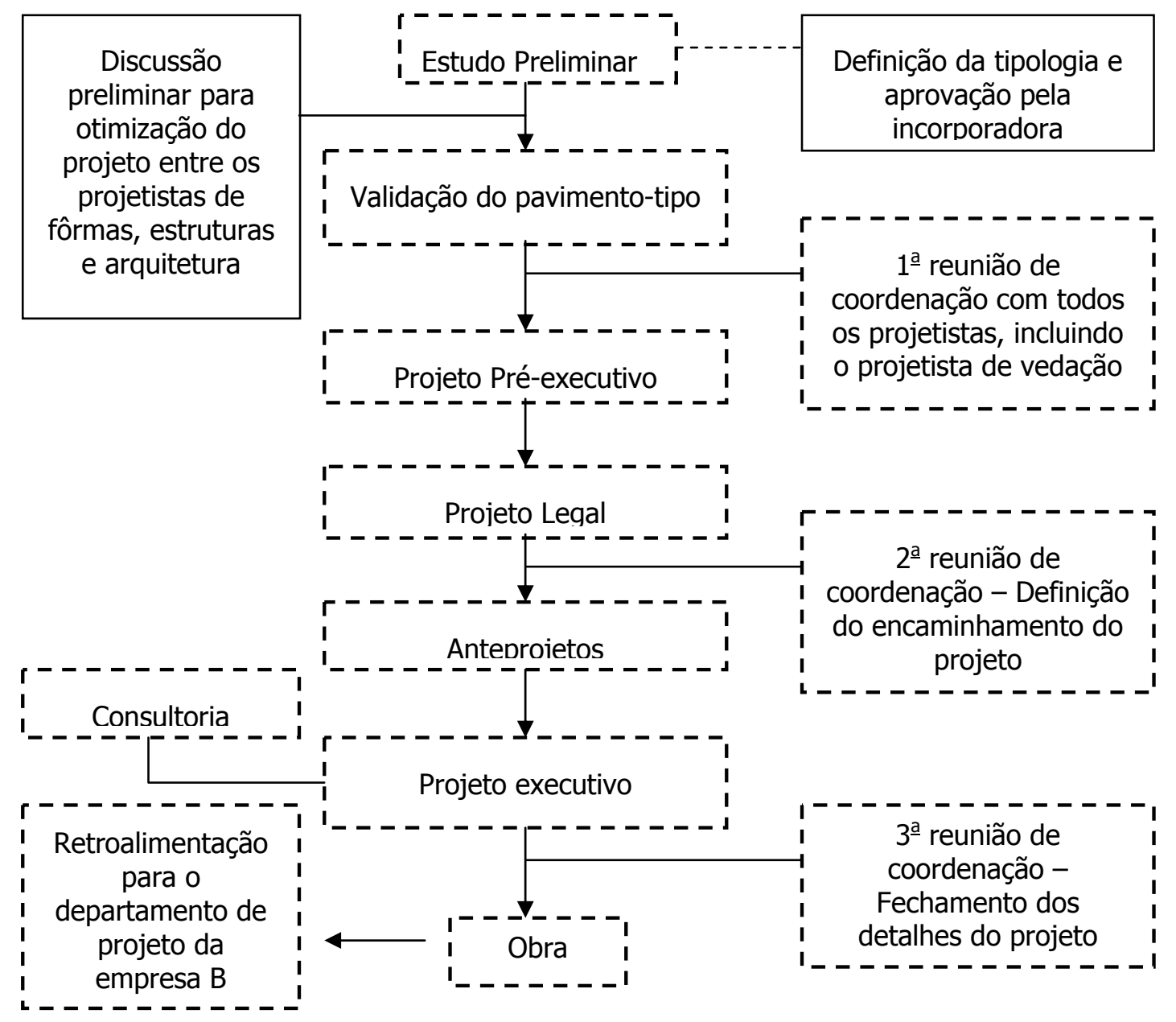

Figura 2: O Processo de Projeto na Empresa B 
Destaca-se a interação entre os projetistas de arquitetura e estruturas na análise do projeto, após o estudo preliminar, com a introdução do projetista de fôrmas nessa análise. São feitas de três a quatro reuniões de coordenação durante o projeto. A primeira é caracterizada pela entrega do caderno de contratação de projetos, que contém os escopos dos projetos, diretrizes de projeto, nomenclatura de diretórios e arquivos de projeto e planejamento das atividades de projeto. As outras reuniões destinam-se ao acompanhamento dos diversos projetos e a eventuais compatibilizações entre eles. O projetista de vedações é contratado juntamente com os demais projetistas, participando desde a primeira reunião de coordenação.

\subsection{O processo de projeto na empresa construtora C}

A empresa C atua no mercado de incorporação e construção há 40 anos, apresentando na época do estudo 14 empreendimentos em andamento. Essa empresa apresenta um departamento de projetos composto por quatro coordenadores de projetos e um gerente de projetos, todos subordinados à Diretoria Técnica da empresa. Os coordenadores de projeto são responsáveis por toda a coordenação do projeto de um empreendimento.

O projeto para produção de vedações verticais foi adotado pela empresa há oito anos com o intuito de racionalizar o processo de execução. Atualmente todos os projetos são contratados de empresas projetistas especializadas, inclusive o projeto para produção de vedações verticais. No entanto, antes de 2003, o projeto para produção de vedações verticais era desenvolvido internamente. Esse procedimento trouxe algumas melhorias para o processo de projeto porque quem projetava conhecia bem a tecnologia construtiva da empresa; no entanto, o volume de obras aumentou e alguns atrasos da entrega do projeto para produção de vedações verticais começaram a ocorrer, o que levou a uma reestruturação e o projetista que desenvolvia os projetos internamente passou a ser uma empresa prestadora de serviços.

O processo de projeto na empresa C está estruturado segundo a Figura 3.

Os projetistas de arquitetura e paisagismo são contratados primeiramente e dão as primeiras definições sobre o pavimento tipo. Os outros projetistas são acionados para definição dos elementos do projeto antes da sua aprovação na prefeitura. A contratação do projetista de vedações só ocorre na elaboração do projeto préexecutivo, quando todos os projetistas são contratados formalmente.

São realizadas, geralmente, de três a quatro grandes reuniões de coordenação de projeto, segundo o procedimento da empresa construtora, podendo ainda dentro da coordenação haver outras reuniões menores.

Um aspecto interessante observado no processo de projeto da empresa $C$ é o fato de, após a definição dos projetos executivos, quando os projetos são entregues à obra, ser feita uma reunião dos diversos projetistas com o engenheiro da obra, encarregados, departamento de qualidade da empresa para a apresentação do projeto de forma global.

A retroalimentação dos problemas ocorridos na obra para o departamento de projetos é falha e só ocorre quando há uma solicitação de alteração de projeto feita pela obra. Mesmo que não se faça solicitação de alteração de projeto na obra, as 
modificações são freqüentes, conforme verificado em visita à obra, as quais não geram retroalimentação para o desenvolvimento de futuros projetos.

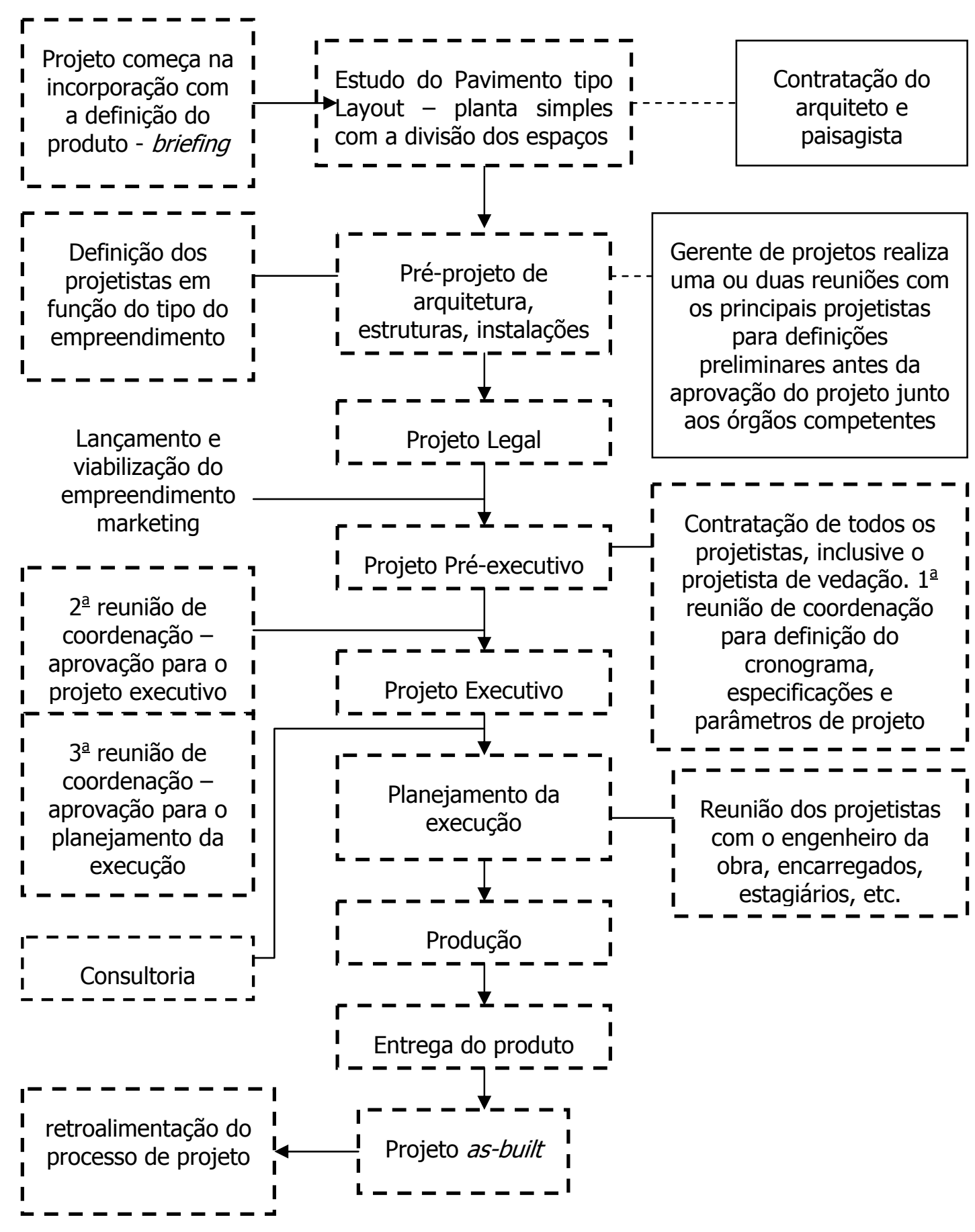

Figura 3: O Processo de Projeto na empresa C

\subsection{O processo de projeto na empresa construtora D}

A empresa D atua no mercado de incorporação e construção há 35 anos e se caracteriza como uma empresa de pequeno porte, construindo em média de três a quatro empreendimentos por ano. 
Essa empresa tem um departamento de projetos, responsável pelo controle de todos os projetos, e todos os projetos são contratados externamente. A coordenação do processo de projeto na empresa construtora também é realizada externamente; normalmente, pela empresa de projeto de arquitetura, pois a equipe interna cuida apenas da análise dos projetos. O processo de projeto na empresa $\mathrm{D}$ está estruturado conforme se vê na Figura 4.

O projeto se inicia com o estudo de viabilidade do empreendimento realizado pelo arquiteto. Os projetistas, inclusive o de vedações, são contratados após a aprovação do projeto nos órgãos competentes e antes da realização do projeto pré-executivo. Durante o processo de projeto são realizadas de oito a dez reuniões de coordenação, que envolvem todos os projetistas, inclusive o de vedações, o coordenador interno de projeto da empresa e o coordenador de obras.

O primeiro projeto para produção de vedações verticais foi contratado pela empresa há cinco anos, quando a obra já estava sendo executada e não no início do processo de projeto, o que resultou em grandes problemas, pois todos os projetos já estavam concebidos e as suas interfaces não resolvidas. A partir dessa experiência, a empresa passou a contratar o projeto para produção de vedações verticais junto com os demais projetos. Ele destacou que os resultados da utilização desse tipo de projeto só são visíveis quando a empresa monitora o seu desenvolvimento, o que se traduz pela melhor qualidade da vedação.

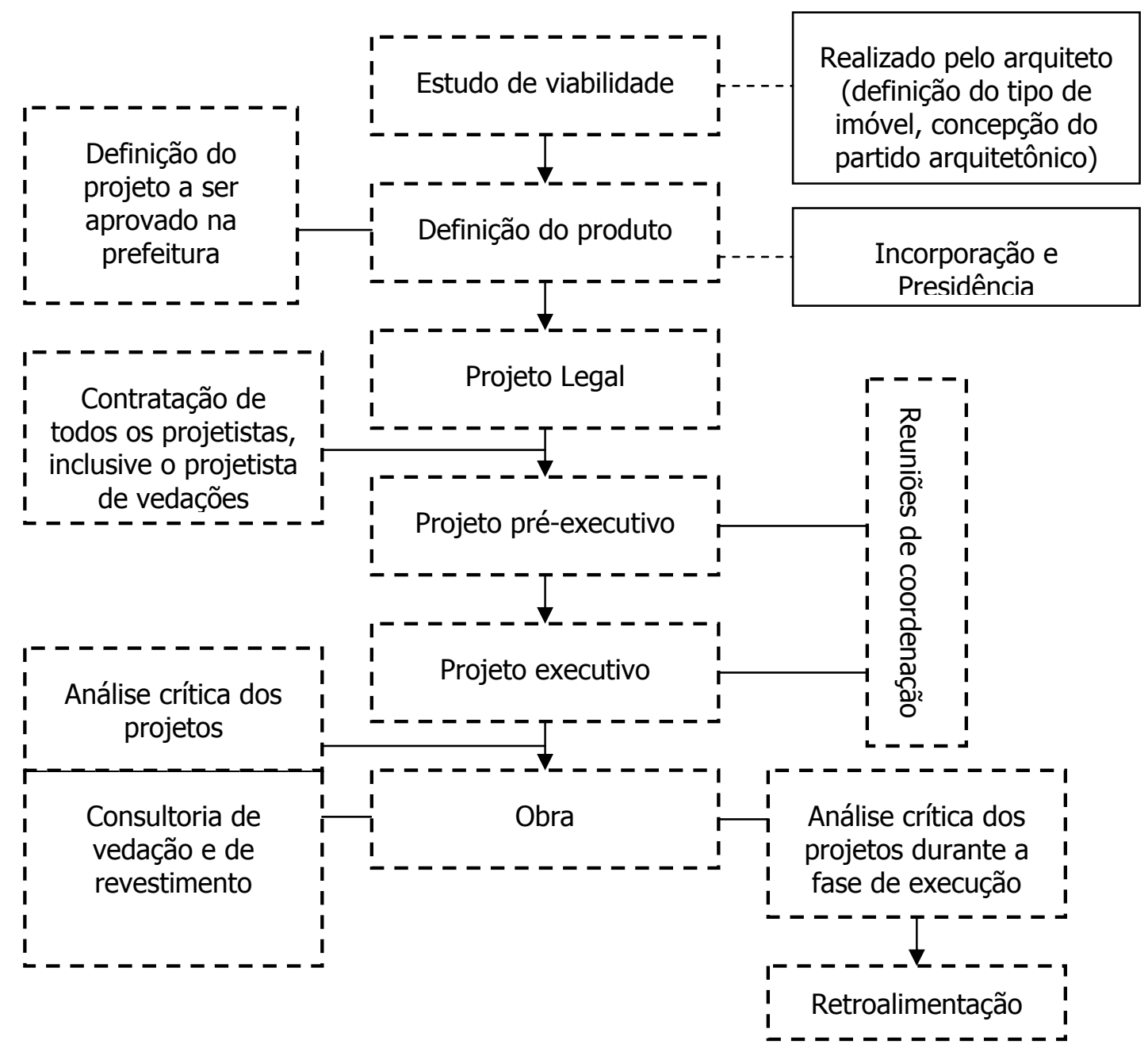

Figura 4: O Processo de Projeto na empresa D 


\subsection{Caracterização das empresas de projeto para produção de vedações verticais}

Na cidade de São Paulo existem pelo menos sete empresas especializadas que desenvolvem projeto para produção de vedações verticais. A Tabela 1 mostra as principais características de quatro dessas empresas que desenvolvem projeto para produção de vedações verticais para as respectivas empresas construtoras estudadas.

Tabela 1: Caracterização das empresas de projeto para produção de vedações verticais

\begin{tabular}{|c|c|c|c|c|}
\hline Aspectos & EP1 & EP2 & EP3 & EP4 \\
\hline $\begin{array}{l}\text { Área de } \\
\text { atuação }\end{array}$ & $\begin{array}{l}\text { Projetos para } \\
\text { produção de vedações } \\
\text { verticais e projetos de } \\
\text { alvenaria estrutural }\end{array}$ & $\begin{array}{c}\text { Projetos para } \\
\text { produção de vedações } \\
\text { verticais e de } \\
\text { revestimentos de } \\
\text { fachada, projetos } \\
\text { arquitetônicos e } \\
\text { coordenação de } \\
\text { projetos }\end{array}$ & $\begin{array}{c}\text { Projetos para } \\
\text { produção de vedações } \\
\text { verticais e } \\
\text { coordenação de } \\
\text { projetos }\end{array}$ & $\begin{array}{c}\text { Projetos para } \\
\text { produção de vedações } \\
\text { verticais e projetos de } \\
\text { arquitetura }\end{array}$ \\
\hline $\begin{array}{l}\text { Tempo de } \\
\text { atuação }\end{array}$ & 5 anos & 10 anos & 9 anos & 1 ano \\
\hline $\begin{array}{c}\text { No projetos / } \\
\text { ano }\end{array}$ & $\begin{array}{l}\text { média de } 30 \text { projetos } \\
\qquad / \text { ano }\end{array}$ & $\begin{array}{l}\text { média de } 80 \text { a } 100 \\
\text { projetos / ano }\end{array}$ & $\begin{array}{c}\text { média de } 100 \text { projetos } \\
\text { /ano }\end{array}$ & $\begin{array}{l}\text { média de } 12 \text { a } 16 \\
\text { projetos / ano }\end{array}$ \\
\hline Fundador & Engenheiro civil & $\begin{array}{l}\text { Engenheiro civil / } \\
\text { Arquiteto }\end{array}$ & Arquiteto & Arquiteto \\
\hline $\begin{array}{c}\text { Principais } \\
\text { características }\end{array}$ & $\begin{array}{c}\text { Parceria com um } \\
\text { fornecedor de blocos } \\
\text { cerâmicos resultou na } \\
\text { criação de um sistema } \\
\text { de blocos pré- } \\
\text { projetados visando } \\
\text { facilitar o projeto, } \\
\text { aumentar a } \\
\text { produtividade e a } \\
\text { qualidade } \\
\text { Mão-de-obra própria } \\
\text { para a execução das } \\
\text { vedações. A empresa } \\
\text { construtora que } \\
\text { contrata o projeto tem } \\
\text { a opção de contratá-lo } \\
\text { juntamente com a } \\
\text { mão-de-obra } \\
\text { Realiza apresentação } \\
\text { do projeto na obra; } \\
\text { faz visitas ao canteiro } \\
\text { de obras quando } \\
\text { solicitadas }\end{array}$ & $\begin{array}{l}\text { Desenvolve projetos } \\
\text { para produção de } \\
\text { vedações verticais em } \\
\text { alvenaria e em gesso } \\
\text { acartonado } \\
\text { Não apresenta o } \\
\text { projeto para produção } \\
\text { de vedações verticais } \\
\text { na obra, salvo quando } \\
\text { solicitado } \\
\text { O número de visitas } \\
\text { ao canteiro de obras é } \\
\text { limitado em contrato; } \\
\text { geralmente é feita } \\
\text { uma visita após a } \\
\text { execução dos } \\
\text { primeiros pavimentos }\end{array}$ & $\begin{array}{l}\text { Desenvolve projetos } \\
\text { para produção de } \\
\text { vedações verticais em } \\
\text { alvenaria e em gesso } \\
\text { acartonado } \\
\text { Não apresenta o } \\
\text { projeto para produção } \\
\text { de vedações verticais } \\
\text { na obra, somente } \\
\text { quando solicitado; } \\
\text { segundo o projetista, } \\
\text { por falta de interesse } \\
\text { das próprias } \\
\text { construtoras } \\
\text { Três visitas ao } \\
\text { canteiro de obras } \\
\text { inseridas em contrato, } \\
\text { mas só as realiza } \\
\text { quando solicitado. } \\
\text { Geralmente realiza a } \\
\text { 1a visita após a } \\
\text { execução dos } \\
\text { primeiros pavimentos, } \\
\text { para modificações de } \\
\text { projeto } \\
\text { Não apresenta } \\
\text { nenhum mecanismo } \\
\text { formal de } \\
\text { retroalimentação }\end{array}$ & $\begin{array}{l}\text { Desenvolve projetos } \\
\text { para produção de } \\
\text { vedações verticais em } \\
\text { alvenaria e em gesso } \\
\text { acartonado } \\
\text { Faz apresentação do } \\
\text { projeto para produção } \\
\text { de vedações verticais } \\
\text { na obra para os } \\
\text { encarregados do } \\
\text { serviço de execução } \\
\text { das vedações e } \\
\text { engenheiros } \\
\text { Normalmente faz uma } \\
\text { vista à obra para a } \\
\text { apresentação do } \\
\text { projeto para produção } \\
\text { de vedações verticais; } \\
\text { uma segunda visita } \\
\text { após a execução do } \\
\text { primeiro pavimento } \\
\text { quando são analisadas } \\
\text { as interferências não } \\
\text { visualizadas no } \\
\text { projeto; e uma } \\
\text { terceira quando } \\
\text { solicitado pela obra }\end{array}$ \\
\hline
\end{tabular}




\subsection{Análise das obras estudadas}

\section{Caracterização da obra A}

A obra A é um edifício residencial cuja construção teve início em novembro de 2001 e término em dezembro de 2003. Apresenta dois subsolos, um pavimento térreo, um mezanino e vinte pavimentos tipo com seis apartamentos por andar, com opção de áreas de 48 e $52 \mathrm{~m} 2$ por apartamento. A obra foi construída com estrutura convencional de concreto armado (fck $25 \mathrm{MPa}$ ), com espessura de laje variando entre 12 e $14 \mathrm{~cm}$, sobre fundação de tubulões à céu aberto. As vedações são de blocos cerâmicos tendo como revestimento interno o gesso aplicado sobre o bloco (exceto no primeiro e último pavimentos) e, como revestimento externo, argamassa projetada e pintura.

\section{Análise do projeto para produção de vedações verticais na obra A}

A execução das vedações na empresa construtora A segue um procedimento padrão. Em todas as obras da empresa o projeto para produção de vedações verticais é repassado à equipe de execução pela empresa projetista por meio da sua apresentação em obra, com o objetivo de facilitar a leitura do projeto e mostrar as soluções adotadas.

Além da apresentação do projeto para produção de vedações verticais, as visitas do projetista geralmente só ocorrem quando solicitado pela obra. $\mathrm{O}$ engenheiro relatou que não houve sua participação direta nas decisões na fase de elaboração desse projeto, ficando a sua participação restrita a contribuições após a execução do primeiro pavimento. Nessa obra, houve uma análise crítica do projeto para produção de vedações verticais após a execução do primeiro pavimento, feita conjuntamente entre o engenheiro residente, o projetista e o gerente de desenvolvimento. $\mathrm{O}$ projeto para produção de vedações verticais foi modificado, durante a execução da vedação, uma única vez - após a visita do projetista para discussão de algumas alterações do projeto com o engenheiro residente.

A prática de analisar criticamente o projeto para produção de vedações verticais após a execução dos primeiros pavimentos permite fazer ajustes e adequar o projeto para a execução nos pavimentos seguintes.

O Gerente de Desenvolvimento destacou que a utilização do projeto para produção de vedações verticais acontece aos poucos, para verificar a familiaridade da equipe de execução com esse projeto. Dessa forma, primeiro é fornecida a planta de locação, observando-se as principais dificuldades. Após é fornecida a planta de marcação e assim sucessivamente, até a completa execução do primeiro pavimento. Por esse aspecto, a execução do primeiro pavimento geralmente demanda mais tempo do que os pavimentos subseqüentes.

O projeto de arquitetura da obra A definia muitas paredes com ângulos diferentes e ainda um desnível na laje do pavimento tipo. Em decorrência, o projetista de vedação optou pela utilização de muitos blocos e pré-moldados para atender à modulação da vedação.

O projeto para produção de vedações verticais analisado especificava uma grande quantidade de modelos de peças especiais (14), modelos de verga (7), modelos de contravergas (5) e peças pré-moldadas (7), além dos blocos de largura e comprimentos variados para atender à modulação horizontal e vertical das 
vedações. As peças especiais resultavam do corte dos blocos no canteiro com disco diamantado ("makita"). As peças pré-moldadas, vergas e contravergas estavam sendo produzidas na própria obra para atendimento da demanda nos andares.

Além da dificuldade de fabricação de alguns pré-moldados, o que se refletiu sobre a velocidade de execução de algumas peças e atrasos na obra, havia a necessidade de controle das peças e de definição de responsabilidades na operação da central.

As questões relativas ao transporte e armazenamento dos materiais necessários à execução das vedações não constavam do projeto para produção de vedações verticais; foram resolvidas pelo engenheiro e pelo mestre-de-obras, de acordo com a disponibilidade de espaço em diversas fases do canteiro.

O procedimento da empresa A preconiza que a argamassa para assentamento da vedação seja fabricada no próprio local, segundo quantidades de materiais predefinidas. Os materiais para a fabricação da argamassa eram transportados para o andar em sacos com quantidades predeterminadas, conforme especificação do traço pelo Gerente de Desenvolvimento, e misturados em uma betoneira de eixo inclinado.

Todas as obras da empresa A apresentam mão-de-obra subcontratada para a execução das vedações e, nessa obra, havia a subcontratação de duas empresas distintas. Foi relatado por um dos subempreiteiros que a falta de um determinado bloco tornou necessário mudar a especificação do projeto quanto à espessura da parede. O projeto especificava para uma parede a espessura de $14 \mathrm{~cm}$, mas na obra só existiam blocos de 11,5cm e estes foram utilizados no lugar dos primeiros.

Foi relatado pelo Gerente de Desenvolvimento o bom entrosamento entre a empresa A e os fornecedores de materiais, que é fruto de uma parceria existente há alguns anos. Há uma preocupação com o desempenho dos materiais utilizados e da vedação final, e não só com o seu aspecto estético. Foram realizados diversos ensaios com blocos e argamassas dos principais fornecedores afim de que parcerias fossem estabelecidas.

As Fotos 1 e 2 mostram a alvenaria de vedação da obra A durante a sua execução.

\section{Problemas identificados na obra A}

Foi possível identificar alguns problemas relativos à execução das vedações, relatados na Tabela 2. Alguns deles resultam da especificação do projeto para produção de vedações verticais, outros da especificação de outros projetos ou das suas interfaces com o projeto para produção de vedações verticais e ainda da desqualificação da mão-de-obra. Ressalta-se que muitos dos problemas relacionados à execução das vedações foram minimizados a partir da execução do terceiro pavimento, quando houve uma maior familiarização da mão-de-obra com o projeto e com o procedimento de execução. 
Tabela 2: Problemas identificados na obra A

\section{Legenda da tabela:}

PEP - problemas relativos à especificação e detalhes do projeto para produção de vedações verticais

POP - problemas relativos à especificação de outros projetos ou de compatibilização entre as interfaces

PGO - problemas relativos à gestão no canteiro de obras

PMO - problemas relativos à mão-de-obra de execução das vedações

\begin{tabular}{|c|c|}
\hline Origem & Problemas \\
\hline \multirow{4}{*}{ PEP } & $\begin{array}{l}\text { Foi especificado um tipo de pré-moldado no projeto para produção de vedações verticais que } \\
\text { não estava se ajustando à modulação da vedação, o que exigiria o seu corte quando da } \\
\text { execução. Após a execução da vedação do primeiro pavimento houve uma modificação de } \\
\text { projeto para que a peça se ajustasse à respectiva parede. }\end{array}$ \\
\hline & $\begin{array}{l}\text { Foi detectada uma parede que constava na planta de locação e marcação, mas não estava } \\
\text { detalhada no caderno de elevações e teve que ser improvisada durante a execução dos } \\
\text { primeiros pavimentos até que chegasse a revisão do projeto. }\end{array}$ \\
\hline & $\begin{array}{l}\text { Pequenas adaptações foram realizadas pela mão-de-obra em algumas paredes, como a } \\
\text { colocação de blocos compensadores que não estavam especificados no projeto para que a } \\
\text { junta não ficasse com uma espessura muito acentuada, mesmo após a revisão do projeto } \\
\text { subseqüente à análise crítica no primeiro pavimento. }\end{array}$ \\
\hline & $\begin{array}{l}\text { Foi verificada quebra de blocos na última fiada para a passagem de eletrodutos, o que não } \\
\text { estava previsto em projeto. }\end{array}$ \\
\hline \multirow{3}{*}{ POP } & $\begin{array}{l}\text { Uma das paredes apresentou uma fissura no seu encontro com o pilar, em todos os andares. } \\
\text { Esse fato foi comunicado ao projetista de estruturas, ao gerente de desenvolvimento e ao } \\
\text { projetista de vedação, que fizeram diversas reuniões para discussão do assunto. Constatou-se } \\
\text { um problema de deformação da laje, confirmado pelo projetista de estruturas. Caracteriza-se } \\
\text { um problema de compatibilização de todos os projetos, já que a solução foi aceita por todos os } \\
\text { projetistas durante o processo de projeto. A solução prevista na obra foi a colagem de um véu } \\
\text { sobre a vedação, antes da execução do revestimento de gesso. }\end{array}$ \\
\hline & $\begin{array}{l}\text { A presença de um desnível na laje (opção arquitetônica) e a definição de apenas um eixo } \\
\text { longitudinal para marcação dificultaram a locação da vedação. }\end{array}$ \\
\hline & $\begin{array}{l}\text { O projeto para produção de vedações verticais não previa a interferência da hidráulica com as } \\
\text { paredes. O procedimento da empresa previa cortes na parede depois de executada para } \\
\text { passagem das tubulações. A solução adotada nesse caso foi cortar a parede com disco } \\
\text { diamantado ("makita"). }\end{array}$ \\
\hline \multirow{3}{*}{ PGO } & $\begin{array}{l}\text { Para uma determinada parede, alguns tipos de blocos foram substituídos por outros que não } \\
\text { estavam especificados, pela falta do componente no momento da execução. }\end{array}$ \\
\hline & Falta de limpeza no andar de execução. \\
\hline & $\begin{array}{c}\text { Algumas paredes apresentaram problemas no prumo ocasionando a sua demolição. O } \\
\text { procedimento especificava tolerâncias para controle do prumo e alinhamento, porém faltou } \\
\text { controle durante a execução da vedação. }\end{array}$ \\
\hline
\end{tabular}


Tabela 2: Problemas identificados na obra A [CONTINUAÇÃO]

\begin{tabular}{|c|c|}
\hline Origem & Problemas \\
\hline \multirow{1}{*}{ PMO } & $\begin{array}{c}\text { Apesar de o projeto para produção de vedações verticais definir a espessura de junta } \\
\text { horizontal de 1cm, a mão-de-obra teve problemas para executá-la, além de não observarem a } \\
\text { cota de saída da } 1^{\text {a }} \text { fiada. Este fato ocasionou uma espessura para fixação muito menor ou } \\
\text { maior do que a prevista. Em alguns casos, houve necessidade de quebrar as últimas fiadas e } \\
\text { até mudar o tipo de bloco especificado. Falta de qualificação da mão-de-obra e falha do } \\
\text { controle de execução da vedação. }\end{array}$ \\
\cline { 2 - 3 } & $\begin{array}{c}\text { Dificuldade para executar a amarração de blocos no encontro de paredes, sendo que a } \\
\text { especificação do projeto para produção de vedações verticais não estava sendo observada pela } \\
\text { mão-de-obra. }\end{array}$ \\
\cline { 2 - 3 } & $\begin{array}{c}\text { Durante a execução dos primeiros pavimentos, verificou-se que os blocos no encontro da } \\
\text { parede com os pilares não estavam sendo comprimidos adequadamente, comprometendo a } \\
\text { aderência entre as interfaces. O procedimento utilizado pela empresa especificava que os } \\
\text { blocos da extremidade no encontro dos pilares deveriam ter a junta totalmente preenchida } \\
\text { com argamassa e ser comprimidos ao pilar. Inexperiência das equipes de execução e falta de } \\
\text { treinamento pela empresa. }\end{array}$ \\
\hline
\end{tabular}

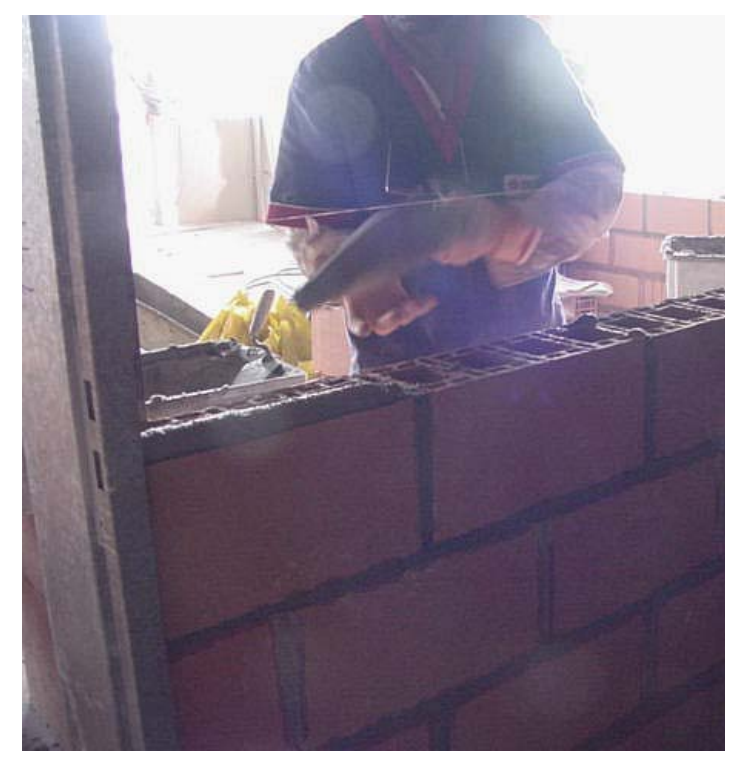

Foto 1: Detalhe da utilização da bisnaga

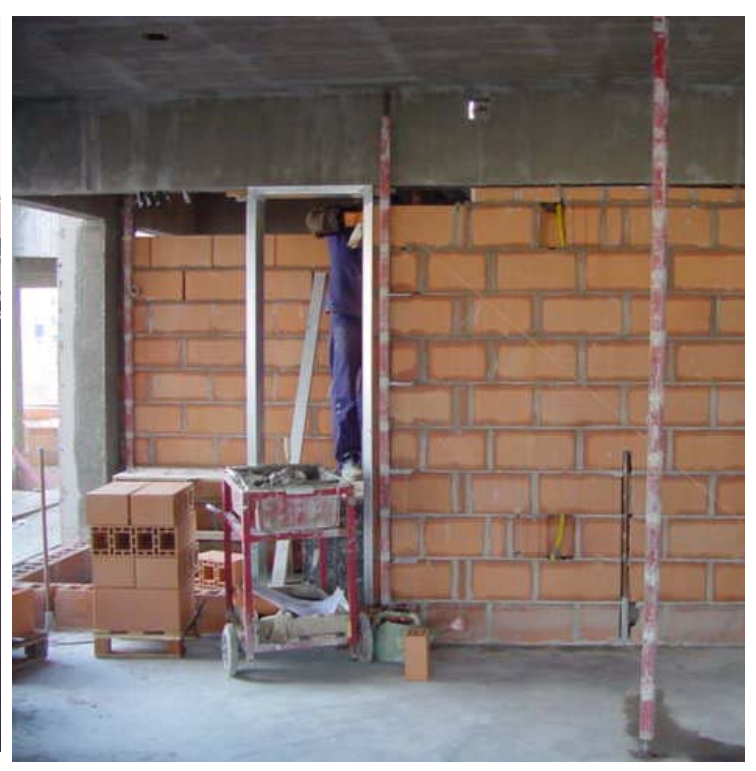

Foto 2: Colocação dos batentes metálicos junto com a elevação da vedação

\section{Caracterização da obra B}

A obra estudada é um edifício residencial com dois subsolos, andar térreo, andar intermediário e 15 pavimentos tipo. Foram utilizados estrutura de concreto armado convencional de fck $30 \mathrm{MPa}$, vedações de alvenaria de blocos de concreto, fundação com hélice contínua e revestimento externo com cerâmica. São dois apartamentos por andar perfazendo uma área de $147 \mathrm{~m} 2$ cada. A obra foi iniciada em janeiro de 2002, sendo o período para entrega de 36 meses. A empresa trabalha com obra a "preço de custo", o que permite aos condôminos, com certas restrições, modificar o projeto inicial conforme as suas necessidades, além das opções de planta préexistentes. 


\section{Análise do projeto para produção de vedações verticais na obra B}

No caso da obra estudada, o projeto para produção de vedações verticais foi desenvolvido por um projetista especializado externo desvinculado do fornecedor dos materiais e a mão-de-obra é da própria empresa construtora. Há uma tendência atual de contratação do sistema fechado de produção1 da vedação possibilitando a garantia das vedações para a construtora. Essa tendência é resultado do aparecimento de diversas manifestações patológicas, implicando em gastos com manutenção para as empresas construtoras. A empresa fornecedora apresenta um caderno de diretrizes de projeto que auxiliam o projetista de produção durante a elaboração do projeto para produção de vedações verticais.

Essa empresa fornecedora, apesar de não fornecer a mão-de-obra e o projeto para produção de vedações verticais, estava responsável pelo fornecimento de todos os materiais utilizados na execução da vedação como blocos, argamassa, pinos e telas, pelo controle da execução e pela garantia da vedação. Inclusive os pré-moldados especificados no projeto para produção de vedações verticais ficaram sob a sua responsabilidade. Para garantir o controle do processo de execução, a empresa fornecedora alocou um estagiário para acompanhamento da execução da vedação na obra, registrando todas as ocorrências, o que é muito útil para a análise crítica do projeto para produção de vedações verticais. Esse estagiário era também responsável pelo planejamento dos materiais necessários à execução da vedação, eximindo a responsabilidade da obra.

Ressalta-se que o projetista de vedação não fez a apresentação do projeto para produção de vedações verticais na obra. Em todas as obras da empresa B, os 1o e 2o pavimentos são utilizados como protótipo para o levantamento de problemas, facilidades e dificuldades do projeto para produção de vedações verticais. Foi feita uma visita do projetista à obra após a análise crítica do projeto, para discussão das principais modificações a serem incorporadas. Os problemas encontrados nessa fase foram discutidos em reunião na obra com representantes da empresa fornecedora, o engenheiro residente e o projetista de vedação.

No caso dessa obra, como o fornecedor de materiais era o responsável pela garantia das vedações, o projetista, apesar de ter responsabilidades legais sobre o seu projeto, não estava comprometido inteiramente com o desempenho das vedações.

Não se observou nesse projeto uma variedade de blocos e pré-moldados que dificultasse a sua execução. No entanto, os aspectos relativos à execução não estavam definidos pelo projeto para produção de vedações verticais, como locais para armazenamento de blocos e argamassa, transporte desses materiais até o andar, definições quanto ao modo de produzir a vedação, equipamentos e ferramentas utilizadas na sua execução. O local para armazenamento dos materiais e o seu transporte na obra são definidos pelo engenheiro e estagiário da obra.

\footnotetext{
${ }^{1}$ Segundo o Manual de Diretrizes para Projetos de Vedação da empresa fornecedora de blocos, esse sistema é "um sistema de produção de vedações completo que integra as etapas de projeto, planejamento, execução e controle do processo produtivo, além dos fornecimentos dos materiais". Caracteriza-se principalmente pela garantia do desempenho adequado da vedação dada pelo fornecedor após a sua execução.
} 
A mão-de-obra era própria, com um total de 40 funcionários, incluindo a administração. Segundo o Gerente de Projetos, a realocação de operários de uma obra para outra é feita de forma descoordenada, existindo ainda muitas dificuldades. O fabricante de blocos dá assistência ao treinamento da mão-de-obra no processo de implementação do projeto para produção de vedações verticais.

Os operários percebem a importância do projeto para produção de vedações verticais, considerando-o como um facilitador para a execução da vedação; estão bastante habituados com o uso do projeto e com o procedimento de execução da empresa; apresentam um bom entrosamento e estão na empresa há pelo menos dois anos.

É preferível, segundo a mão-de-obra, o caderno de elevações nos formatos A4 ou A3, facilitando o manuseio durante a execução. Houve comentários sobre algumas medidas que seriam relevantes e deveriam constar no projeto, como a distância do encontro de duas paredes até o caixilho. Também se comentou sobre a dificuldade da numeração das paredes do projeto da obra estudada, dificultando a memorização do projeto.

Na obra B, a execução da hidráulica é feita junto com a elevação da parede. A equipe de execução verificou algumas dificuldades em relação aos ajustes na modulação da vedação e espessura de paredes para passagem de tubulação hidráulica, provocando desperdício de material (bloco), dificuldade de execução e incertezas quanto à estabilidade e desempenho da parede no futuro.

As Fotos 3 a 7 mostram a alvenaria de vedação da obra B durante a sua execução.

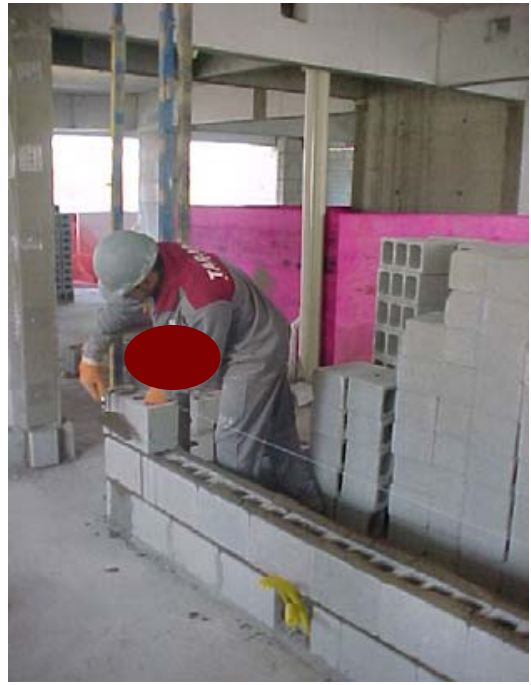

Foto 3: Detalhe da elevação

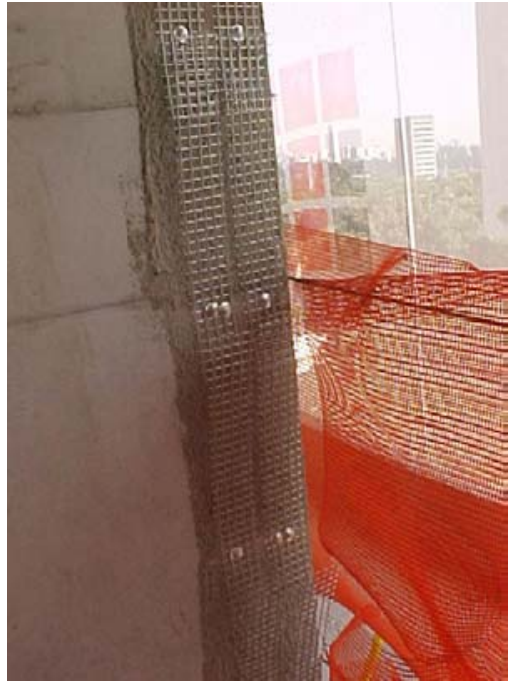

Foto 4: Detalhe da ligação estruturaparede

\section{Problemas identificados na obra B}

A Tabela 3 apresenta os principais problemas verificados na obra B. 


\section{Tabela 3: Problemas identificados na obra B}

\section{Legenda:}

PEP - problemas relativos à especificação e detalhes do projeto para produção de vedações verticais POP - problemas relativos à especificação de outros projetos ou de compatibilização entre as interfaces PGO - problemas relativos à gestão no canteiro de obras

PMO - problemas relativos à mão-de-obra de execucão das vedacões

\begin{tabular}{|c|c|}
\hline Origem & Problemas \\
\hline \multirow{7}{*}{ PEP } & Algumas paredes tiveram a sua modulação modificada para que as juntas não ficassem \\
aprumadas.
\end{tabular}

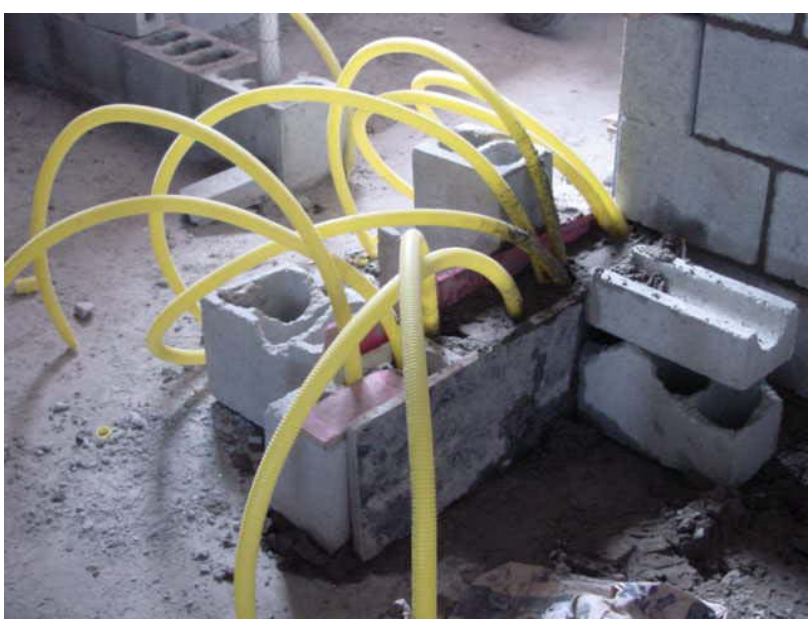

Foto 5: Detalhe da parede do quadro de distribuição - improvisação na obra 


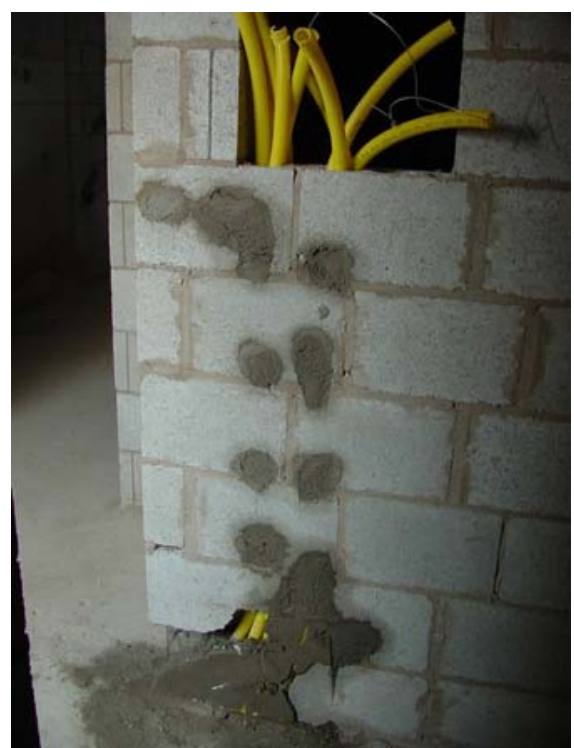

Foto 6: Parede do quadro de distribuição

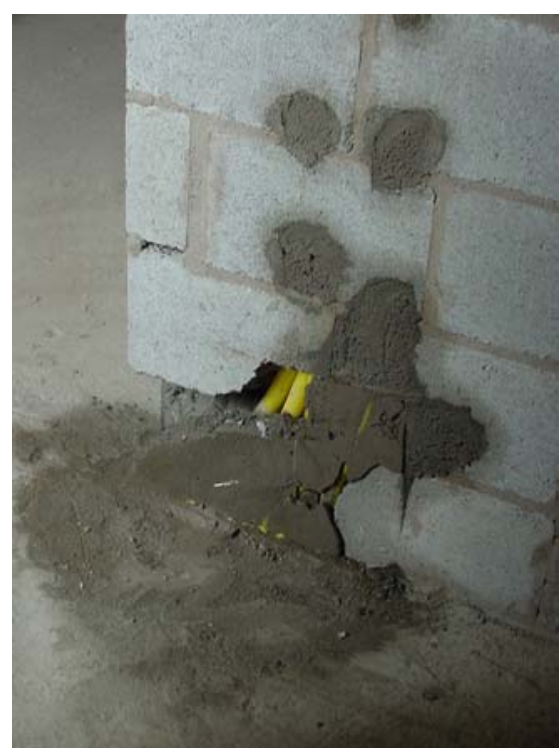

Foto 7: Parede do quadro de distribuição

\section{Caracterização da obra C}

A obra estudada é um edifício residencial cuja construção teve início em março de 2003 e apresenta 24 pavimentos tipo com 309m2 de área cada, sendo um apartamento por andar, um andar térreo, um mezanino e dois subsolos. Construído com estrutura convencional de concreto armado e vedações de blocos cerâmicos. O revestimento interno é gesso sobre bloco nas áreas secas e ajulezo/ cerâmica nas áreas molhadas, o revestimento de fachada é cerâmico e as instalações elétricas e hidráulicas são embutidas nas paredes de vedação. Ressalta-se que a obra estava sendo vendida a "preço de custo", o que significa que a arquitetura do pavimento tipo pode sofrer modificações durante a execução da obra a critério do cliente. Isso tem implicações sobre a execução da vedação se o planejamento das modificações a serem efetuadas não coincidir com o planejamento da execução da vedação para o pavimento em questão, o que inevitavelmente ocasiona quebras de blocos, rasgos na vedação, etc.

\section{Análise do projeto para produção de vedações verticais na obra C}

Sobre a solução adotada no projeto para produção de vedações verticais, verificouse na obra $C$ que o projeto de arquitetura bastante simples, sem uso de soluções arquitetônicas mais arrojadas, foi um facilitador para a concepção de uma vedação sem muitas dificuldades, de projeto ou de execução.

Na obra C, a mão-de-obra subcontratada é de uma empresa de projeto de vedação, a EP1, cujo projeto para produção de vedações verticais foi analisado quando do estudo da empresa A na respectiva obra. No caso da obra C, o projeto para produção de vedações verticais foi contratado de uma outra empresa de projeto especializada (EP4) e somente a mão-de-obra foi contratada da EP1. A contratação da EP1 contemplava a mão-de-obra treinada para execução da vedação, fornecimento de todos os materiais como argamassa, blocos e telas, ferramentas e equipamentos, inclusive definição dos locais de armazenamento dos materiais na obra. 
Verificaram-se alguns problemas na interface projeto-execução. Nessa obra e em outras da empresa $C$, o projeto para produção de vedações verticais é normalmente contratado da EP4, a qual já está habituada a projetar para a empresa C. O projeto para produção de vedações verticais desenvolvido pela EP4 diferencia-se dos demais por não apresentar um caderno de elevações com vistas e detalhes de todas as paredes de vedação. Ao invés do caderno de elevações, há uma planta mostrando detalhes das principais paredes, principalmente aquelas que tem uma interface com as instalações hidráulicas. As demais paredes podem ser executadas com o auxilio de uma planta de 1 a e 2a fiadas que fazem parte do escopo desse projeto.

Como o subempreiteiro contratado também é uma empresa de projeto para produção de vedações verticais e a forma de apresentação do seu projeto é diferente da adotada pela EP4, o subempreiteiro, visando uma melhor produtividade da sua mão-de-obra, optou por redesenhar todo o projeto no formato que a sua equipe de execução está habituada, ou seja, com a vista de todas as paredes no caderno de elevações. Portanto, o projeto para produção de vedações verticais que foi utilizado na obra não é o projeto desenvolvido pelo projetista de produção contratado e que havia sido compatibilizado com os demais projetos. $\mathrm{O}$ primeiro projeto para produção de vedações verticais tornou-se obsoleto, tendo sido utilizadas apenas as plantas de furação elétrica e hidráulica durante a execução da estrutura. E ainda gerou necessidade de conferência das interfaces desse novo projeto com os projetos de arquitetura, instalações hidráulicas e elétricas e estrutura no próprio canteiro de obras.

Assim, o projetista que participou de todo o projeto não teve nenhuma relação com a obra, e nem elementos para a retroalimentação de futuros projetos; toda a assistência para a execução da vedação foi direcionada para o subempreiteiro, diretamente entre ele e a obra, sem envolver o departamento de projeto da empresa construtora.

A análise crítica do projeto para produção de vedações verticais também é realizada após a execução do primeiro pavimento (protótipo) para se fazer os principais ajustes no projeto. Destaca-se que após a construção do protótipo, projetistas do empreendimento de outras especialidades também participam dessa visita.

O projeto para produção de vedações verticais utilizado na obra $C$ não trazia definições sobre armazenamento e transporte de materiais, fornecimento e disposição de equipamentos, soluções para aumento da produtividade ou planejamento da execução.

Nesse caso, a responsabilidade pelo fornecimento, armazenamento, transporte e controle dos materiais relativos à vedação era do subempreiteiro. Alguns procedimentos, no entanto, são da própria empresa $\mathrm{C}$, como no caso do preparo de argamassa para assentamento da vedação, que era pré-dosada em sacos plásticos de areia e cimento em uma central montada no canteiro de obras e misturada no andar de execução por meio de uma argamassadeira e/ ou uma betoneira de eixo inclinado.

A obra utilizava um elevador tipo cremalheira que estava fazendo todo o transporte vertical desses materiais. A central de pré-dosagem de argamassa estava 
próxima ao elevador, facilitando o seu transporte para o andar de execução. Também foi montada uma central na própria obra para a fabricação dos prémoldados, a qual ficava sob a responsabilidade da subempreiteira.

O procedimento da empresa construtora previa uso de telas metálicas a cada duas fiadas da vedação, nos encontros entre paredes e pilares e em alguns encontros entre paredes. No entanto, um consultor contratado pela empresa C, após desenvolvido o projeto para produção de vedações verticais, definiu que não haveria a necessidade de telas em todos os encontros e foram feitas modificações no projeto.

\section{Problemas identificados na obra C}

Os principais problemas verificados na obra C estão representados na Tabela 4.

\section{Tabela 4: Problemas identificados na obra C}

\section{Legenda}

PEP - problemas relativos à especificação e detalhes do projeto para produção de vedações verticais

POP - problemas relativos à especificação de outros projetos ou de compatibilização entre as interfaces

PGO - problemas relativos à gestão no canteiro de obras

PMO - problemas relativos à mão-de-obra de execução das vedações

\begin{tabular}{|c|c|}
\hline Origem & Problemas \\
\hline \multirow[t]{2}{*}{ PEP } & $\begin{array}{c}\text { O projeto para produção de vedações verticais definia telas metálicas a cada duas fiadas nos } \\
\text { encontros de paredes com a estrutura e em alguns encontros entre paredes. Houve } \\
\text { modificação dessa especificação após análise desse projeto por consultor contratado pela } \\
\text { empresa construtora }\end{array}$ \\
\hline & $\begin{array}{l}\text { Houve algumas modificações de locais de caixinhas elétricas e padronização das distâncias } \\
\text { horizontais das caixinhas às portas, as quais não estavam definidas }\end{array}$ \\
\hline \multirow[t]{2}{*}{ POP } & $\begin{array}{l}\text { Houve modificações em algumas paredes para definição de rebaixos para a passagem de } \\
\text { tubulações hidráulicas, os quais não estavam previstos. Caracteriza-se um problema de } \\
\text { compatibilização entre o projeto para produção de vedações verticais e o projeto de sistemas } \\
\text { hidráulicos }\end{array}$ \\
\hline & Problemas na interface entre a coordenação do projeto e a execução da obra \\
\hline PGO & $\begin{array}{c}\text { Problemas na coordenação entre o planejamento da execução da vedação e o prazo para as } \\
\text { mudanças no apartamento sugeridas pelo cliente. Com isso, houve desperdício de materiais } \\
\text { pela execução de rasgos em paredes, o que não potencializa o projeto para produção de } \\
\text { vedações verticais. }\end{array}$ \\
\hline
\end{tabular}

As Fotos 8 e 9 mostram a alvenaria de vedação da obra $C$ durante a sua execução. 


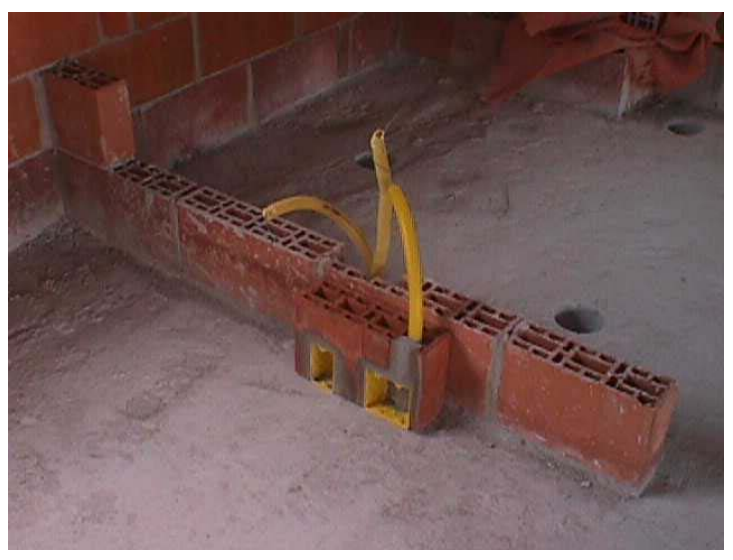

Foto 8: Detalhe da locação da vedação

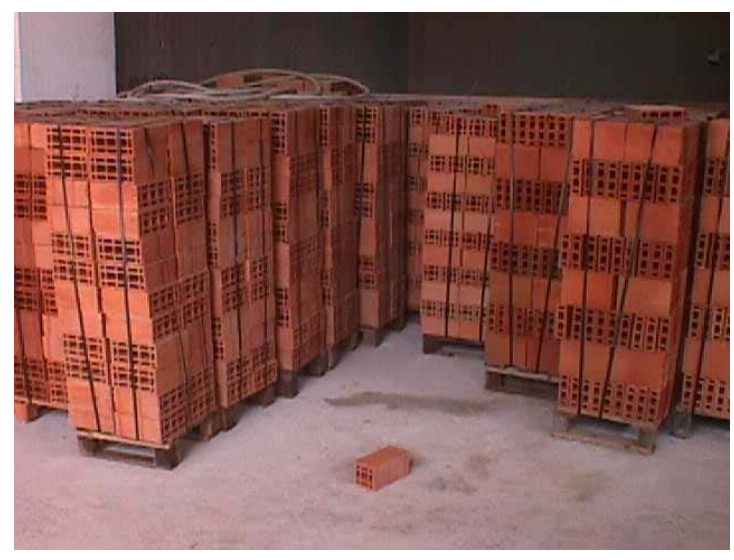

Foto 9: Armazenamento de blocos em páletes

\section{Caracterização da obra D}

A obra da empresa D é um edifício residencial com 15 pavimentos-tipo, 18 apartamentos por andar, um atiço, um térreo e três subsolos. Os apartamentos são do tipo quarto, cozinha, estúdio e banheiro. Foram utilizadas estrutura convencional de concreto armado e vedações em alvenaria de blocos de concreto. Como revestimento interno foi utilizado gesso sobre o bloco nas áreas secas e cerâmica nas áreas molhadas, e como revestimento externo argamassa e pintura. As instalações elétricas são todas embutidas e as instalações hidráulicas aparentes, com carenagem.

\section{Análise do projeto para produção de vedações verticais na obra D}

A empresa D contratou o projeto para produção de vedações verticais da EP3. Foi relatado que o projetista de vedações é contratado no início do processo de projeto junto com os demais projetistas. No entanto, em alguns casos a empresa recorre ao projetista para uma consulta sobre questões referentes à vedação antes dessa contratação formal e antes da aprovação do projeto legal.

Além da tentativa de estabelecer parceria com o projetista de vedações e com outros projetistas no decorrer do tempo, a empresa $\mathrm{D}$ vem criando outras parcerias com fornecedores de mão-de-obra e materiais. A empresa utilizou algum tempo o sistema fechado de produção. O projeto para produção de vedações verticais da obra D foi desenvolvido para atender o tipo de bloco dessa empresa fornecedora. Antes do início da obra e após o projeto para produção de vedações verticais pronto, a empresa D não pôde mais contratar os serviços dessa fornecedora, mas resolveu tentar estabelecer a mesma estrutura da empresa fornecedora na execução da vedação da obra D. Para isso, contratou os subempreiteiros de mão-de-obra da empresa fornecedora, os quais já estavam habituados com o projeto para produção de vedações verticais.

Foi contratado também um consultor, para acompanhamento direto da execução da vedação, visando evitar manifestações patológicas futuras. O consultor iniciou por uma análise inicial do projeto para produção de vedações verticais que já estava pronto, mas cuja execução ainda não havia iniciado. A solução de projeto apresentada definia uso de telas metálicas em todos os encontros de parede com 
pilares, mas uma análise técnica revelou que não havia necessidade dessas telas em todos os encontros, o que possibilitou uma economia significativa e um ganho de produtividade para a obra. No entanto, essas modificações poderiam ter sido consideradas durante o processo de projeto se o consultor tivesse sido contratado anteriormente.

Apesar do envolvimento do projetista de vedações durante o projeto, o coordenador de obras destacou o pouco envolvimento desse profissional durante a execução; não houve a apresentação do projeto à equipe da obra e o projetista fez apenas uma visita, após a execução do primeiro pavimento (protótipo), promovendo-se algumas modificações.

O projeto para produção de vedações verticais não apresenta as questões referentes à logística do canteiro, locais de armazenamento e forma de transporte dos materiais, ou a ferramentas e equipamentos para execução. $\mathrm{O}$ consultor relatou o exemplo do transporte vertical utilizado na obra, que não foi pensado adequadamente; os elevadores eram muito lentos e à medida que houve a necessidade de transportar materiais para andares mais altos, o sistema ficou comprometido e houve algumas interrupções na execução da vedação.

\section{Problemas ocorridos na obra D}

Os principais problemas identificados na obra D são apresentados na Tabela 5.

Tabela 5: Problemas identificados na obra D

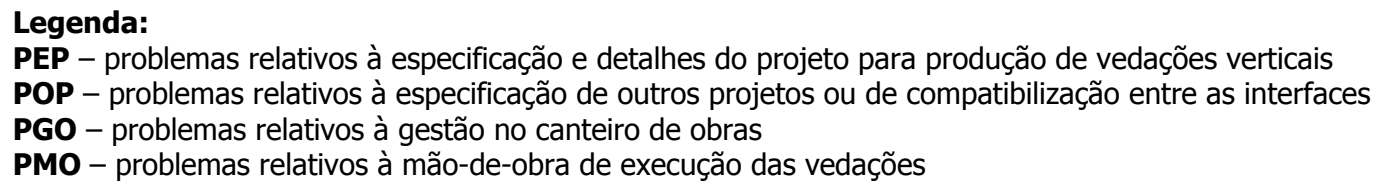

\begin{tabular}{|c|c|}
\hline Origem & Problemas \\
\hline \multirow{3}{*}{ PEP } & $\begin{array}{l}\text { O projeto para produção de vedações verticais definia telas metálicas em todos os encontros } \\
\text { de paredes com a estrutura. Houve modificação dessa especificação após análise desse projeto } \\
\text { por consultor contratado pela empresa construtora. }\end{array}$ \\
\hline & $\begin{array}{c}\text { Shaft do banheiro e das sacadas do pavimento tipo não estavam definidas em projeto. } \\
\text { Exemplo: a parede da sacada não formava um ângulo reto no encontro com o pilar e } \\
\text { dependendo do tipo de amarração poderia ocasionar fissuras. Isso foi previsto após análise } \\
\text { técnica do consultor na obra }\end{array}$ \\
\hline & $\begin{array}{l}\text { O projeto para produção de vedações verticais não trazia especificações acerca de detalhes } \\
\text { construtivos. Exemplo: sobre os reforços de vergas de portas e a vedação sobre a qual se } \\
\text { apoiava, o projeto para produção de vedações verticais mandava prever o reforço, mas não } \\
\text { especificava qual e como, o que transportou para a obra toda a escolha e decisão }\end{array}$ \\
\hline POP & $\begin{array}{c}\text { Dificuldade na interface da vedação com as instalações hidráulicas provocando alguns } \\
\text { problemas de execução na obra. Caracteriza-se a necessidade de estudos das interfaces entre } \\
\text { esses projetos }\end{array}$ \\
\hline PMO & $\begin{array}{l}\text { Dificuldade de controle da mão-de-obra na execução de detalhes específicos da execução da } \\
\text { vedação que fazem parte do procedimento da empresa }\end{array}$ \\
\hline PGO & $\begin{array}{c}\text { Opção por fabricar pré-moldados especificados pelo projeto para produção de vedações } \\
\text { verticais na própria obra comprometeu a sua qualidade final }\end{array}$ \\
\hline
\end{tabular}


As Fotos 10 e 11 mostram a alvenaria de vedação da obra D durante a sua execução.

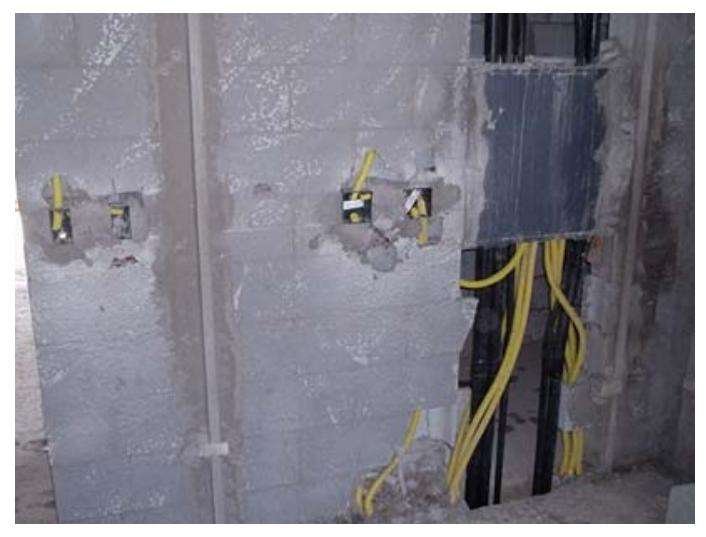

Foto 10: Parede do quadro de elétrica

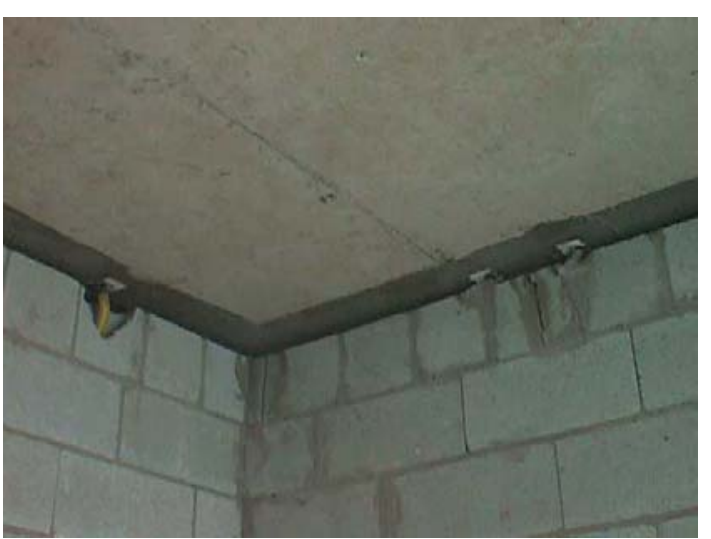

Foto 11: Interface com a tubulação

\section{CONCLUSÕES}

\subsection{Quanto às empresas construtoras}

As empresas construtoras estudadas dedicam uma atenção especial à qualidade dos seus empreendimentos e consideram o projeto para produção de vedações verticais um elemento importante para a racionalização construtiva. Verificaram-se esforços para a melhoria do processo de projeto nessas empresas, como a inserção do projetista desde as primeiras etapas do projeto, contratação de consultores, introdução de programa de racionalização, etc.

Os processos de projeto analisados, no entanto, demonstraram uma forte incidência de falhas na interface dos projetos com o projeto para produção de vedações verticais, principalmente com o projeto de arquitetura e instalações, comprovadas por problemas relatados nas obras. $\mathrm{O}$ incorporador tem uma forte influência sobre as definições do projeto de arquitetura e isso muitas vezes leva a soluções de projeto que não são as mais adequadas. Esse fato foi verificado na empresa A, em que a solução do projeto de arquitetura dificultou a solução para o projeto para produção de vedações verticais e gerou problemas para sua execução. Na empresa $\mathrm{C}$, o processo de projeto falha principalmente na interface com a obra, em que o todo o esforço para desenvolvimento do projeto para produção de vedações verticais é perdido quando o projeto é redefinido na obra. E, em todas as empresas estudadas, a interface do projeto para produção de vedações verticais com os projetos de instalações elétricas e hidráulicas ainda não está bem resolvida.

\subsection{Quanto às empresas de projeto}

As empresas de projeto de vedações apresentam um volume de projetos muito grande, ao mesmo tempo em que têm quadros muito enxutos de funcionários. Verificou-se que o projeto para produção de vedações verticais é definido sem adequada consideração de aspectos relativos ao desempenho das vedações. Os escopos desses projetos praticados pelas empresas de vedações praticamente 
apresentam a mesma proposta: plantas de locação e marcação da 1a fiada, distribuição dos pontos de elétrica e hidráulica, caderno de elevações e algumas especificações que, muitas vezes, são do próprio procedimento da empresa construtora.

Apesar desses profissionais serem contratados cada vez mais nas primeiras etapas do processo de projeto, verificou-se uma dificuldade para a discussão de soluções mais viáveis com os demais projetistas. O que ocorre é a compatibilização do projeto para produção de vedações verticais com os projetos já definidos. Considerações de questões relativas a custos, produtividade e desempenho não foram observadas nos projetos para produção de vedações verticais estudados.

Longe de ser um traço cultural apenas do projetista de vedação, os projetistas, de um modo geral, não acompanham a implementação do seu projeto no canteiro de obras, salvo quando solicitados pela própria obra. Isso compromete o desempenho do projeto, principalmente no caso de projetos que têm uma interface muito grande com a execução, como o projeto para produção de vedações verticais, com grande influência sobre os custos de execução e também sobre o arranjo dos canteiros de obras.

\subsection{Quanto à interface do projeto com a execução}

Apesar de as empresas construtoras estarem cada vez mais voltadas à redução de desperdícios em suas obras, o controle da execução ainda é pouco sistemático nas obras observadas, realizado normalmente após a execução das vedações. Além disso, os mecanismos para a retroalimentação dos problemas ocorridos em obra para as empresas construtoras foram considerados falhos em todas as empresas.

O projeto para produção de vedações verticais não define a logística no canteiro, normalmente ela é definida pelo engenheiro ou encarregados do serviço de execução da vedação, fato observado em todas as obras visitadas. Muitos dos problemas identificados nas obras são reflexos não só das especificações do projeto para produção de vedações verticais, mas também de aspectos relativos à gestão dos materiais e à gestão da mão-de-obra.

A relação com os fornecedores de materiais apresenta uma tendência de contratação de um sistema fechado de produção, ficando o fornecedor também responsável pelo desempenho da vedação.

\subsection{Conclusões gerais}

O desenvolvimento do projeto para produção de vedações verticais requer um esforço consciente dos diversos agentes do processo de produção, que resulte em ações integradas na busca do conhecimento da tecnologia construtiva empregada pelas empresas construtoras e suas interferências no canteiro de obras, dos materiais e equipamentos empregados, da análise custo-benefício das soluções de projeto, desempenho do subsistema, logística do canteiro e controle do processo de produção, somadas a uma retroalimentação eficiente para futuros projetos e para todo o processo de produção.

Os estudos realizados indicam que há uma deficiência nos projetos para produção em relação às considerações sobre desempenho do subsistema vedações. Muitas 
vezes, as vedações dos nossos edifícios não estão sendo projetadas com base em requisitos de desempenho previamente estabelecidos, mas sob a égide do empirismo. Do ponto de vista setorial, as diversas entidades representativas têm um papel fundamental na mudança de postura quanto à normalização técnica, pois devem contribuir para que novas normas entrem em vigor e outras sejam atualizadas.

Tema que ainda não foi devidamente explorado, ficou claro a importância da avaliação do desempenho dos projetos para produção, que deve servir também como instrumento para retroalimentação do processo de projeto e das estratégias globais do empreendimento, quanto à tecnologia construtiva, formas de contratação de projetistas e de mão-de-obra de execução, assim como de organização do canteiro de obras. Essa avaliação deve ser realizada durante o seu desenvolvimento, durante a sua implementação e após a execução do subsistema projetado.

\section{REFERÊNCIA BIBLIOGRÁFICA}

AQUINO, J.P.R. Análise do desenvolvimento e da utilização de projetos para produção de vedações verticais na construção de edifícios. $184 \mathrm{p}$. Dissertação (Mestrado) - Escola Politécnica, Universidade de São Paulo. São Paulo, 2004.

\section{BIBLIOGRAFIA CONSULTADA}

DUEÑAS PEÑA, M. Método para elaboração de projetos para produção de vedações verticais em alvenaria. 160p. Dissertação (Mestrado) - Escola Politécnica, Universidade de São Paulo. São Paulo, 2003.

MELHADO, S.B. Qualidade do projeto na construção de edifícios: aplicação ao caso das empresas de incorporação e construção. 294p. Tese (Doutorado) - Escola Politécnica, Universidade de São Paulo, São Paulo, 1994.

MELHADO, S.B.; BARROS, M.M.S.B.; SOUZA, A.L.R. Diretrizes para elaboração do projeto de alvenaria de vedação. São Paulo: EPUSP, 1995. (Relatório final / não publicado)

MELHADO, S.B.; FABRÍCIO, M.M. Projetos da produção e projetos para produção na construção de edifícios: discussão e síntese de conceitos. In: ENCONTRO NACIONAL DE TECNOLOGIA DO AMBIENTE CONSTRUÍDO: QUALIDADE NO PROCESSO CONSTRUTIVO, 7., Florianópolis, 1998. Anais. Santa Catarina: 1998. p.731-737.

SABBATINI, F.H. A industrialização e o processo de produção de vedações: utopia ou elemento de competitividade empresarial. In: SEMINÁRIO VEDAÇÕES VERTICAIS, 1, 1998, São Paulo. Anais... São Paulo: EPUSP, 1998. p.1-20. 